\title{
"But we Will Always Have to Individualise". Police Supervision of Released Prisoners, its 'Crisis' and Reform in Prussia (1880-1914)
}

Philipp Müller

\section{(2) OpenEdition Journals}

Electronic version

URL: https://journals.openedition.org/chs/1190

DOI: $10.4000 /$ chs. 1190

ISSN: 1663-4837

\section{Publisher}

Librairie Droz

\section{Printed version}

Date of publication: 1 December 2010

Number of pages: $55-84$

ISBN: 978-2-600-01470-0

ISSN: 1422-0857

\section{Electronic reference}

Philipp Müller, "'But we Will Always Have to Individualise". Police Supervision of Released Prisoners, its 'Crisis' and Reform in Prussia (1880-1914)", Crime, Histoire \& Sociétés / Crime, History \& Societies

[Online], Vol. 14, n² | 2010, Online since 01 December 2013, connection on 24 March 2022. URL: http://journals.openedition.org/chs/1190 ; DOI: https://doi.org/10.4000/chs.1190 


\title{
"But we Will Always Have to Individualise" Police Supervision of Released Prisoners, its 'Crisis' and Reform in Prussia (1880-1914)
}

\author{
Philipp Müller²
}

\begin{abstract}
Cet article étudie une forme particulière de sanction en Prusse, la surveillance de haute police. La surveillance de haute police était une peine complémentaire imposée aux détenus après leur libération. Bien que sa finalité fût de préserver la loi et l'ordre en intégrant soigneusement les ex-prisonniers, "l'échec de l'amendement [du condamné] était un élément essentiel de la logique» de la surveillance policière. Cet article approfondit notre compréhension de l'histoire de cette forme de châtiment grâce à l'examen de cette pratique et de sa réforme. La surveillance de haute police était contestée; son utilisation était critiquée par les avocats de sa réforme, et le ministère de l'Intérieur prussien lui-même fut alerté en 1866 du fait qu'elle ne remplissait pas les fonctions de la surveillance de haute police. Le style notoirement militaire de la police prussienne, tout comme les pratiques persistantes des policiers locaux sur le terrain, et la conception même du contrôle de la police, tout cela mettait en péril la prise en charge et la surveillance des anciens détenus. Au tournant du siècle, un ensemble de réformes s'efforcèrent de modifier fondamentalement la situation en introduisant une "prise en charge suivie»-c'est-à-dire une approche plus individualisante - sous la responsabilité de sociétés de bienfaisance. Toutefois, je démontre que ces réformes n'ont pas remédié aux carences de la surveillance de haute police; l'«échec de l'amendement» se perpétua, quoique sous une forme nouvelle.
\end{abstract}

This paper examines a particular form of punishment in Prussia: the institution of police supervision. Police supervision was an additional punishment imposed on prisoners after their release from prison. Although it was meant to safeguard law and order by carefully integrating former prisoners,

Martin Peltasohn (1849-1912), GStA I. HA Rep. 84 Nr. 7935, Minutes of the Prussian Diet 11./12.1.1907, 89 .

I thank the Heimatmuseum Köpenick and the Landeskirchliche Archiv Berlin Brandenburg for the kind permission to publish original pieces of their holdings.

2 Dr Philipp Müller is Lecturer in Modern German History at University College London. Prior to his current position he obtained his Ph.D. at the European University Institute in Florence. Subsequently he was Post Doctoral Fellowship at the Research Centre Media of History-History of Media at the Universität Weimar and the Universität Erfurt. He specialises in the field of the history of crime, police and media. Selected Publications: Auf der Suche nach dem Täter. Dramatisierung von Verbrechen im Berlin des Kaiserreichs, Campus: Frankfurt a.M., 2005 (Historische Studien; 40); “'Éducateur' ou 'mauvais garçon'? Le capitaine de Köpenick et les bouleversements du paysage médiatique dans l'Allemagne de Guillaume II." (Requate, Les médias au XIXe siècle, 2009, pp. 89-99). 
"the failure of betterment [of the convict] was an essential element of the logic" 3 of police supervision. This article deepens our insight into the history of this form of punishment by examining the practise of supervision and its reform. Police supervision was contested; its handling was criticised by advocates of reform, and even the Prussian Interior Ministry was alerted in 1866 that the current practises did not match with the aims of police supervision. The notorious military style of policing in Prussia, as well as persistent policing practises of local policemen on the beat and the design of police supervision itself, jeopardised the care and the surveillance of ex-prisoners. By the turn of the century, a set of reforms sought to make a fundamental difference by introducing a "monitoring care" under the responsibility of welfare societies: an enhanced individualising approach to remedy the situation. However, as I will show, the reforms did not successfully address the shortcomings of police supervision; the "failure of betterment" continued, even if it took on a new form.

\section{"MORAL CARE" AND THE "POLICE TONE"}

$\mathrm{O}$ ne could describe the shortcomings of police supervision in late nineteenth and early twentieth century Prussia in terms of a conflict: two basic principles, those of tutelage and independence, contradicted each other. As prison chaplain Braune posited, "moral care" (sittliche Pflege) was required without patronization or any "tone of police" (Polizei-Ton) 4 . However, to abandon any form of surveillance went against the grain of police supervision as it presumed an asymmetrical relationship and necessitated both confinement and liberty. The repercussions of this theme can be traced in the legal history of police supervision. There were two different laws regulating the intervention of the police, the "Law on police supervision" (Gesetz über die Polizeiaufsicht) and the "Law on the admission of settling persons of 31 December 1842" (Gesetz über die Aufnahme zuziehender Personen vom 31. Dezember 1842). While the latter remained unchanged throughout the period, the proportions of legal constraints and the police's permissions to intervene regulated in the law on police supervision shifted throughout the 19th century.

Generally the punishment of the convicted person was alleviated - while the police discretionary powers were increasingly restricted. The codification of the constitution in Prussia (1848/1850) marked a first step in this long-term development as "the formulation of maxims for the practice of the police was deemed desirable." The police's powers of 'indeterminate sentencing' gave way to regulations of the Napoleonic Code pénal that had been implemented in some parts of Prussia during Napoleon's imperialism (the western provinces on the left bank of the Rhine and the Duchy of Berg). From the beginning of the new constitutional regime in 1850, imposing police supervision required the decision of a court ${ }^{6}$. In 1870 the Imperial

Lüdtke (1982, p. 237); cf. Lüdtke (1989, p. 131).

Braune (1884, p. 112); Funk (1986, p. 164).

5 Goltdammer (1851, p. 148); See also Funk (1986, p. 145). Regarding other German states: Anonymous (1884), R. (1884), Wagner (1886), Fuhr (1892), Nußbaum (1909, p. 275f., p. 279f.); Rosenfeld (1910, p. 297ff.).

6 Lüdtke (1989, p. 128); cf. Fuhr (1892, p. 150f.); Funk (1986, p. 80f.). 
Penal Code introduced further elements that softened the conditions of police supervision: the punishment's maximum duration of ten years was reduced to five, and the concept of "night time" (Nachtzeit) which forbade certain offenders from leaving their home during the night was abolished; finally, police supervision was no longer a compulsory "additional punishment" (Nebenstrafe) for particular types of criminals determined by the court, but had now become an option to be considered by the police at the end of the prison sentence ${ }^{7}$. These modifications suggest an increasing regulation of policing, a 'taming' of the police, while released prisoners were continuously granted more liberty. However, the 1842 Right of Residence Law continued to guarantee the police's wide ranging powers as it was entirely in the hands of the police to allow persons to enter a police district or to expel them for an unlimited period of time ${ }^{8}$. It was this law of 1842 , coexisting with the legal provisions about police supervision, which enabled the police to continue with more violent forms of policing'.

The focus of this article is the juxtaposition, if not interdependent interlocking, of granted rights and legal confinements, of coercion and support, of distant surveillance and subtle intrusion. I will examine the tools and means of police supervision put in place to administer a specific social milieu in the context of the history of the Prussian Police in the Imperial period. This study will provide an analysis of these "power relationships" (relations de pouvoir) ${ }^{10}$, including the strategies deployed by the agencies involved in carrying out the supervision, the diverse conditions under which the strategies were applied, and their effects or the lack thereof on the "sentenced individuals" (verurteilten Elemente) ${ }^{11}$. The article consists of the following parts: In the first part I highlight the shortcomings of the policing practices as traditionally understood, the tacit assumptions about the 'administered' and the right of the police to expel former prisoners; The second part provides an analysis of the particular rhetorical appropriation of these problems by the penal reform movement and its political result: the reforms of police supervision initiated between 1895 and 1907. The third part examines the changes and continuities of the newly reformed police supervision; and, finally, I assess the problems that arose in spite of the promised effects.

\section{POLICE SUPERVISION IN PRUSSIA}

Police supervision was defined as an "additional punishment" (Nebenstrafe) of prisoners after their release from prison. The notion underlying this form of punishment considered a recently released prisoner not an autonomous person in social and legal terms, but a disabled social being: former prisoners challenged by their sudden freedom required control. Hence the limitation of the ex-prisoner's civic rights. The

Fuhr (1892, p. 168f., p. 186f.); Braune (1889, p. 818); GStA I. HA Rep. 84 Nr. 7935, Decree 30.6.1900, 42, 43; cf. Roth (1997, p. 281); cf. Müller (2006, p. 62f).

8 Nussbaum (1909, p. 358).

9 For a very helpful critique of our notion of the 'modernisation of law and justice': Habermas (2009a, pp. 37-41).

10 Foucault (1981, p. 136, 1979, 2004, pp. 3-6, p. 4); Lüdtke (1979, 1991).

11 GStA I. HA Rep. 84 Nr. 7935, Decree 4.2.1907, 94ff., 94. 
confinement of the freedom of a sentenced person was subject to change during the constitutional transformation of the Prussian Kingdom during the second half of the 19th century. However, two crucial means of intervention remained in the hands of the police throughout the period: the local police were authorised to search the former prisoner's house, to confine his or her mobility (including specific places and localities), and, ultimately, to expel the former prisoner altogether out of the police district (Polizeibezirk) ${ }^{12}$.

The typical ex-prisoner under police supervision was male while female offenders were seldom sentenced to police supervision ${ }^{13}$. However, all of them shared the same characteristic: an entry in their criminal records indicating their prosecution for property offences ${ }^{14}$. Karl Fuhr, an expert on penal law and a disciple of Franz von Liszt (1859-1919), concluded in 1886 that the district police authority opted for police supervision more than 90 per cent of cases if the prisoner had been sentenced for committing a property crime ${ }^{15}$. Metaphorically speaking, 'the thief', the epitome of delinquency in the 19 th century ${ }^{16}$, was the main concern of both the courts and the police. A close monitoring process was to follow after the property offender's release thus turning the released prisoner into an "observat", an observed individual.

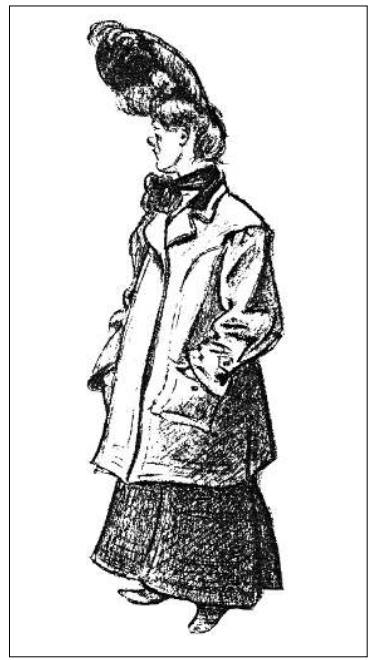

Illustration one: Heinrich Zille "Bleak Prospects: Badly dressed and subjugated to police supervision one is not able to make better acquaintances."

12 GStA I. HA Rep. 84 Nr. 7935, Decree 30.6.1900, 41ff. [\$8].

13 For example, in 1903, a prison chaplain at the prison in Görlitz reported that out of twenty-one convicts nineteen were male, only three female, see Braune (1903, p. 759), see also Kr. (1883); Wagner (1886). In 1902 the Verein zur Besserung der Strafgefangenen reported about 213 male and twentyfour female clients, the Verein der Berliner Stadtmission noted fifty-two male and three female "protégées", Landeskirchliches Archiv Berlin Brandenburg (LAAB ) 14/1508, Bericht der Centralstelle (1902), 13ff. Similar proportions of males and females are to be found in other reports. The vast majority of prisoners were male, only few female, reflecting the gendered performance of crime and its prosecution by the police and justice system. Police supervision, focusing mainly on male petty criminals, was the equivalent to the police surveillance of prostitutes, cf. Nienhaus (1992); Schulte (1979); Evans (1998, p. 166ff.).

14 Lüdtke (1982, p. 237).

15 Fuhr (1892, p. 231).

16 Habermas (2006, 2009b). 
"Observat", "Polizeiobservate" or "Observanden," were the most common denominations used by the involved authorities to label their object of concern. The jargon, however, is misleading if one takes the administrative terms for granted. The notion "Observat" supposes an abstract and disciplined mode of active observation while the object of observation is passive, meaning it is excluded from the operation of observing. However, the police's gaze was neither in permanent control of the sentenced persons nor did the observation operate in a neutral and detached way. On the contrary the gaze of the police was biased and value-laden; already the police's favoured choice of observation, a source of concern, was largely informed by a social stereotype: 'the thief.' Furthermore, the object of police surveillance did not remain passive. "Observate" were actively involved in the process of supervision as they were officially required to be, at least in part. Nevertheless, released prisoners appropriated the conditions of their status as "Observat" according to their own needs and interests. As a consequence, they not only contributed to the outcome but also shaped the conditions to which they were subjected.

In theory, and to safeguard public safety, police monitored the way of life and the development of prisoners after their release. In order to prevent them from relapsing into any criminal activities, the police was therefore "to produce and to uphold by permanent supervision the notion that every step [of the ex-prisoner] was monitored and that the police was informed of anything he did" ${ }^{17}$. In doing so former prisoners were urged to accustom themselves to honest occupation and to permanent respectable business ${ }^{18}$. An industrious way of life would further the disciplinarisation process and thus contribute to the safety of society. Yet, despite the eyes of the police being "always alert and open" ${ }^{19}$, this did not per se translate into the desired effects, namely the reintegration of the former prisoner under ever closer control.

\section{WATCHING: PANOPTIC ILLUSIONS}

Two key elements of police supervision, the industriousness of the ex-prisoner and the surveillance of the police, were in uneasy juxtaposition. Time and again the successive interior ministers reminded subordinate authorities "that the police control of provisionally released prisoners should not be applied in a way so that the released is hampered in his progress or exposed to public contempt" ${ }^{\prime 20}$. Already in 1866 the Minister urged the police to avoid "any public attention" ${ }^{21}$ when monitoring former prisoners. However, the ex-prisoner had little opportunity to escape the "Erinyes of the evil deed" 22 ; the police continued to haunt the wrongdoer and made him live a restless and fugitive life. Mostly the "Erinyes" would manifest them-

17 Fuhr (1892, p. 264).

18 Zimmermann (1979 [1847], p. 366f.); Fuhr (1892, p. 188, 1888); GStA I. HA Rep. 84 Nr. 7935 , Decree 4.2.1907, 94.

19 Fuhr (1892, pp. 164, 264).

20 GStA I. HA Rep. 84 Nr. 7935, Writ 10.2.1904, 76 [original emphasis]; Ibid. Decree 30.6.1900, 41 [\$9]; ibid., Writ 10.2.1904, 76 [in regard to the decree of 12.4.1871].

${ }^{21}$ Instruction of the Interior Minister 22.5.1866, in Fuhr (1892, p. 339), cf. ibid. (p. 182ff.).; GStA I. HA Rep. 84 Nr. 7935, Decree 4.5.1907, 102.

22 Fuhr (1892, p. 230). 
selves in the form of local policemen. In accordance with their monitoring task they regularly looked after their "observate" either in their private home or at their workplace $^{23}$. However, the policeman's regular check on a released prisoner raised suspicion among housemates, neighbours, and employers and, consequently, alerted them to the deviant past of the recently released, but settled ex-prisoner. In contrast to sweeping panoptic illusions, the "alert and open eye" of the local police did not operate from an invisible position ${ }^{24}$, but was instead carried out in public and therefore noticed by "respectable citizens." Given their own understanding of deviancy, "respectable citizens" felt that their "honour" was insulted and that the police's public observation of a sentenced person prompted distrust and hostility ${ }^{25}$. The 'administered' were often sacked by their employers and had to leave after the revelations of their infamous past.

Take the example of Ernst Heidrich. The "assistant painter" (Malergehilfe) was to experience more than once the police's involvement in the unequal distribution and organisation of opportunities in society. Having been released after serving more than five years in gaol, the painter had found work again. Very soon, however, Heidrich faced intrusion from the police and was laid off by his employer. Subsequently, the painter would experience the same treatment detrimental to his integration in society several times. After the painter had found work, policemen would inform his masters about their assistant's recent past and the painter's dismissal would shortly follow ${ }^{26}$.

The brief story of Ernst Heidrich was one of many circulated in diverse media of the time. Such compelling cases fuelled the debate about the shortcomings of police supervision and conveyed only one message, namely the urgency of a reform of this institute. Prison chaplains, pastors, playwrights, lawyers and experts in penal law, all claimed to have a say in the affairs of the police by spreading the narrative of the tragic victim of police supervision. However, local policemen checking on an "Observat" in public was routine practice. To fully comprehend the policemen's actions, we must put aside the biased statements of the reformers and presume that the authorities' policing practices operated with some degree of coherency. Safety was the chief concern of the police and their perception of the problem and how to address it slightly differed from the opinions held by the advocates of reform. Appearing in person from time to time was a police activity informed by traditional practices of policing. A police manual of 1828 depicted the task of monitoring accordingly:

Persons, with whom the individual under observation is in contact, and with the same reputation, must be ascertained. His neighbours should be asked how he obtains his subsistence. Public houses must be asked how much he consumes there and how often and how high he gambles ${ }^{27}$.

23 Instruction of the Interior Minister 22.5.1866, in Fuhr (1892, p. 338); GStA I. HA Rep. 84 Nr. 7935 , Decree 4.5.1907, 102; ibid., Decree 30.6.1900, 44; ibid., Writ 26.3.1907, 96.

24 Foucault (1975, p. 203).

25 Anonymous (1884, p. 158).

26 GStA I. HA Rep. 84 Nr. 7935, Frankfurter Zeitung 18.5.1908, 108; ibid., Volks-Zeitung 13.5.1908, 107; ibid., Newspaper Article 23.5.1908, 109; see also Berliner Börsen Courier 28.12.1911; Fuhr (1982, p. 229).

27 Zeller (1828, p. 48ff.), according to Lüdtke (1989, p. 128). 
For the policemen, the safety of their district mattered; "Snooping and informing" ${ }^{28}$ on ex-prisoners' living conditions were unquestioned everyday policing practices.

Other means of policing reveal a similar kind of thought rooted in traditional modes of police work. Apparently, policemen as well as district authorities often published the name and criminal record of a fugitive "Observat" 29 . The chance to arrest an ex-prisoner in hiding was limited, but the mere possibility of tracking down a disappeared "Observat" by publishing "lists of wanted criminals" gave nimbus of power. The official action and its impression of effective performance weighed more than its potential social impact. Former prisoners in hiding were rarely caught, but, given the revelations of their criminal records, they were often forced to pack their bags again.

This handling of supervision resonates with the overall bureaucratic mode of policing in the Prussian Kingdom. Prussian police was requested to fulfil an allencompassing administration of society regulated by numerous and detailed instructions which made themselves felt in daily life. Commanding tone, authoritarian instructions and bureaucratic police arbitrariness dominated policing by local policemen on the beat ${ }^{30}$. It did not help that the military attitudes and ethos were the main source for the police's practices. Only after nine years of military drill and influence from the army was a non-commissioned officer deemed an appropriate candidate for another but related service, namely the Prussian police ${ }^{31}$. This military training was not without effect on policing, and the experience of drilling, expectations of obedience, and the use of coercion was passed onto the 'subjects'. Consequently, for the "bureaucratic soldier" 32 , supervising an ex-prisoner was an instruction to be enforced in order to safeguard public safety. Accomplishing this task did not require any reflection concerning means, circumstances, or consequences.

\section{REPORTING: FICTIONS OF GOVERNANCE}

The control of a sentenced person's mobility (Konfination, Verstrickung), another component of police supervision, also reflects the prevalent policing à la mode bureaucratique. The implicit expectations of obedience and subjugation of the released prisoner were tied into the monitoring procedures. In accordance with the regulation, a person subjugated to police supervision was obliged to report any move:

To avoid a penalty for delay for up to 300 Mark, which in case of insolvency is to be commuted into a prison sentence for up to four weeks for every instance of non-compliance, you are instructed:

1 , to register at any place, where you stay longer than 24 hours, within 24 hours after your arrival. The registration is to be done in person, in exceptional cases where this is not possible due to extraordinary circumstances, in particular illness,

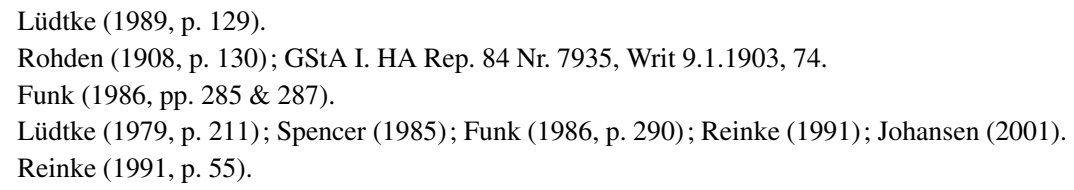


the registration can be done in writing including the mentioning of your whereabouts;

2 , to report to the local police authority every change of address in one and the same locality within 24 hours, including the new address;

3 , to report to the local police authority any change of address 24 hours before your departure from the locality ${ }^{33}$.

Whenever an ex-prisoner wanted to leave the district of the local police, the "Observat" was obliged to report on his or her movements. In other words, police supervision effectively installed a continuous tracking of the administered person ${ }^{34}$. The idea underlying the concept of "Observat" was a permanent observation, suggesting the option to take alleged "asocial elements" in preventive custody at all times.

Nevertheless, the idea of a permanent visibility of the "Observat" relied on the co-operation of the latter. It was the ex-prisoner who was obliged to report to the police about his or her sojourns, about changes of residence, etc.; only these cooperative acts furnished the authority with the required information. It was thus the "Observat" who enabled the police to observe. The efficiency of police supervision presumed the obedience and the compliance of the ex-prisoner with the official instructions taken for granted by state authorities. However, the official subjugation under a specific policing regiment did not result in law-abiding behaviour ${ }^{35}$ as they went underground instead.

\section{EXPELLING: FICTIONS OF BANNING}

A similar effect resulted from the ultimate resort of police supervision: the expulsion of the "Observat" from the police district. The police district authorities were allowed to decide on the expulsion of the 'policed'. If they deemed the presence of the former prisoner to constitute a high risk to "public security and morality" monitoring could give way to expulsion. In an attempt to prevent any breach of the law within the territorial confinement of the police district those who were deemed "very dangerous" were to leave. However this measure of last resort remained an ambiguous strategy deployed to safeguard public safety. The banning of a person from the territory, although a gesture of absolute power, also marked the end of the monitoring process and left the observing agency in the dark.

Time and again contemporaries noted the inefficiency of these measures. Former prisoners escaped the gaze of the police by non-compliance with orders and instructions $^{36}$. A prominent example of this is the infamous Captain from Köpenick. Prior to his notorious coup wearing the stolen uniform of a Prussian military officer, Wilhelm Voigt (1849-1922) was expelled by the Berlin police in August 1906 because he was generally considered to constitute a threat to public security. The

33 GStA I. HA Rep. 84, Nr. 7935, Decree 30.6.1900, 41ff., 43; LAB Pr. Br. Rep. 030, Nr. 1091, Copy of writ 29.12.1905, 73f., 73.

34 See also Lüdtke (1989, p. 128).

35 Fuhr (1892, p. 236f.); Freudenthal (1912, p. 132f.); Roth (1997, p. 283).

36 Fuhr (1892, p. 236f.); see also GStA I. HA Rep. 84 Nr. 7935, Posener Zeitung 30.12.1906, 83 [Max Richter]; Fuhr, Strafrechtspflege, 271 [an anonymous gardener]. 
recently released prisoner, however, did not follow the authorities' order to leave the Berlin area. When asked about Wilhelm Voigt's whereabouts, his sister Bertha Menz told the local police in Rixdorf that her brother had left for Hamburg ${ }^{37}$. The police rightly doubted the accuracy of this report and correctly assumed that their former "Observat" had gone into hiding in Berlin, knowing that Voigt had rented a room in Langestraße $22^{38}$. The police ordered the necessary "penal control" (Strafkontrolle) of the expellee and demanded his arrest in the official police report ${ }^{39}$. These measures neither helped to identify the wanted "Observat" in Berlin in late summer 1906 nor did they prevent the reappearance of Wilhelm Voigt as bogus Captain in October 1906.

\section{PRUSSIAN POLICING: CLAMP DOWN AND LACK OF CONTROL}

The discrepancy between the theoretical idea of supervision and its actual practice in daily life is palpable. In contrast to intriguing ideas such as "unlimited custodial powers" and "invisible but permanent supervision," Prussian police lacked the ability to install a regime as pictured in the decrees and regulations. The administrative effort of police authorities was enormous; the result, as the police headquarters in Berlin admitted, was "null"40. Despite the symbolic effort in displaying police authority and its close relationship to the army, the policing practice of the Prussian police reveals a type of governance which was characterised by clamp-down and lack of control. Given the limited personnel, the recruiting patterns of the police and the prevalent bureaucratic policing style this should not come as surprise. While the authoritarian and rigid mode of policing and the military conduct of policemen was only one side of the coin, the other side displayed helplessness, disinformation and frustration. Nonetheless, in practice both the authoritarian and violent style as well as its limitations were interlinked and enhanced each other.

The policy of the Prussian police in Berlin provides a prime example of the juxtaposition of severity and helplessness, harshness and frustration. The Berlin police headquarters were leading in imposing police supervision on former prisoners ${ }^{41}$ and, in addition, pursued a rigorous policy of expulsion. It was the urban environment of Berlin and the political significance of this particular site which entailed a strong bias and a sufficient excuse for these methods: both shaped the measures taken by Berlin police headquarters. The capital was conceived in metaphors of the Big City ${ }^{42}$ and was considered a "reservoir of sentenced elements" ${ }^{43}$. Hopes for better living and working conditions made people of lesser means move to Berlin and, in the eyes of the police, increased the likelihood of deviant and criminal activities. Hence the capital was considered critical. In order to keep "sentenced elements" (verurteilte

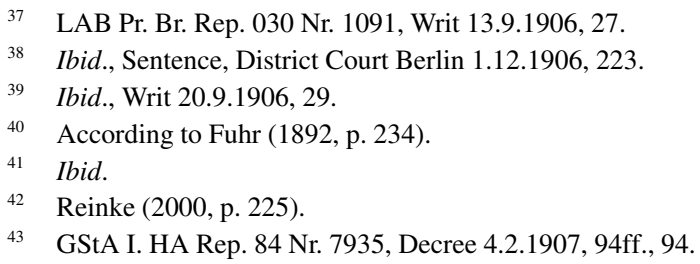


Elemente) out of Berlin, guidelines were drawn up, facilitating the expulsion of former prisoners "personally known as particularly dangerous criminals :" "Observate" who had been prosecuted for "committing sex crimes, perverse sexual actions, brutal offences and certain dangerous crimes against property" were to be expelled ${ }^{44}$. Although the Berlin headquarters were directly subordinated to the Interior Ministry, the minister's repeated demands for the consideration of the individuality of 'the administered' were ignored. The mere presence of allegedly "dangerous criminals" in the Imperial capital raised the concern about the current security situation, the notorious "exekutive Sicherheitsvorbehalt," and resulted in a constant expulsion of ex-prisoners ${ }^{45}$. However, expelling an ex-prisoner from Berlin and its surrounding areas marked the end of police surveillance: despite the harsh measures it had predictably little effect.

Nevertheless, one should not forget to consider the social consequences of the Janus-faced character of police supervision for those who were subjugated to this type of criminal control. Clamp down and lack of control affected those placed under police supervision in two ways. Certainly, released prisoners could easily thwart the efforts of the police and go underground. But in spite of the romantic idea of subversion, we must consider the difficulties and obstacles of such a way of life that was not freely chosen in the first place. Considering the practices of the police, the ex-prisoner's wayward appropriation of the police instructions were often the only means of settling for a time. Furthermore, living underground was fraught with difficulties and restrictions. Their (temporarily confined) attempt and desire to live a "decent life" ${ }^{46}$ was dependent on the good will of tenants, possibly neighbours, and employers. The danger of another expulsion by the police, of arrest, or of a revelation concerning their criminal past, loomed large and was detrimental to the establishing of a stable way of life in whatever form.

\section{THE DISCOURSE OF PENAL REFORM}

The restless way of life of released prisoners, their frequent loss of work and property, their immediate experience of police violence, their suffering from social discrimination by "respectable citizens," and, finally, their yearning for a "decent life", all this was used to a good effect by the movement for penal reform. For reformers police supervision was a "chain of the penitentiary whose clanking sound follows the sentenced individuals for his entire life": ${ }^{47}$ Police supervision was left like a "tattoo which one never gets rid off," a "mark of Cain" which excluded exprisoners "forever" from society ${ }^{48}$. The 'administered' were turned into objects of pity while the police was reproached for its application of police supervision, par-

$44 \quad$ Ibid.; cf. ibid., Berliner Lokal-Anzeiger 12.2.1907, 88.

45 The contradiction is built in the logic of the writing of the decree GStA I. HA Rep. 84 Nr. 7935 , Decree 4.2.1907, 94ff., 94; Schlichting/Reckes (1908, pp. 376f., 380, 385); Aus dem preussischen Strafvollzug (1909, p. 15).

46 LAAB 14/1508, Bericht des Vereins zur Fürsorge entlassener Strafgefangene in Cottbus (1902), Cottbus 1903, 4.

47 Braune (1908, p. 36).

48 Bahn (1907, p. 82); cf. Caplan (1997). 
ticularly the lack of any acknowledgment of the individual conditions and of the exprisoners' character. The handling of police supervision appeared arbitrary and harsh ${ }^{49}$. Whether in postcards, songs, news, plays, novels or articles in expert journals ${ }^{50}$, protagonists of reform asserted the counterproductive effects of police supervision in diverse media by presenting the story of the "tragic victim" of police supervision. Drawing on the scientific notion of "the disabled man"51, an ex-prisoner's relapse into crime was conceived as a product of his or her social milieu. After release from prison the former prisoner strove to live a decent life and found work, but unjust police measures would lead to the repeated break-up of the settled. The story about Wilhelm Voigt was just the most successful repetition of this well-established narrative ${ }^{52}$.

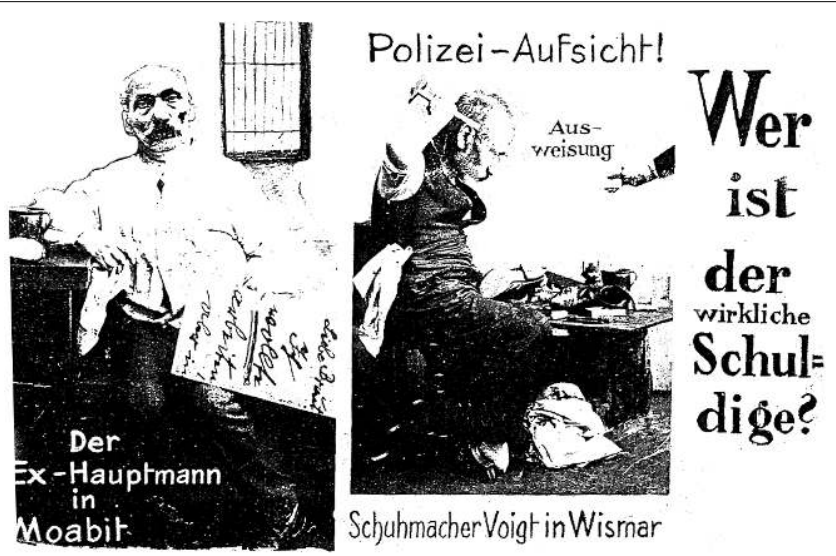

Illustration two: Postcard "Who is the real culprit? Police Supervision," Heimatmuseum Köpenick () 2011

"Police Supervision!" is the title of the post card. On the left side we see the bogus "Captain" from Köpenick imprisoned in a cell in Moabit. An unfinished letter in his hands begins with the words, "Dear Bride. I wanted to work, but in..." The missing is visualised on the postcard's other half. Here Wilhelm Voigt is identified as "Shoemaker Voigt in Wismar" while working in a shop. From the far right a hand reaches into the picture holding a card inscribed with "expulsion." Wilhelm Voigt had found a job and lived an honest live in Wismar after his release from gaol in February 1905. However, the police expelled the former prisoner in May 1905 because of his alleged danger to "public safety and morality," and by October 1906 Voigt

49 Fuhr (1892, p. 202); Braune (1903, p. 821f.); idem (1908, p. 40); Freudenthal (1912, p. 133); GStA I. HA Rep. 84 Nr. 7935, Minutes of the Prussian Diet 11./12.1.1907, 89.

50 HMK Bildarchiv Nr. 437/00, published in Müller (2006, p. 60); Sudermann (1905), Hübner (1900), Fuhr (1892), Zille (1908, p. 57), Wulffen (1908).

$51 \quad$ Becker (1999, p. 371); idem (2002); Habermas (2003, p. 149).

52 Müller (2002); Hett (2003); idem (2004); Müller (2005). 
relapsed into crime. Apparently police supervision which ignored the individual character and situation produced delinquency. Suffice it to say the entire debate of penal reform resonates in this illustration of the Voigt Case.

\section{THE REFORM OF POLICE SUPERVISION (1895-1907)}

The widespread criticism by reformers, backed by the wider movement for penal reform, resulted in the introduction of a number of important changes. The Interior Ministry embarked on a first reform in 1895. Essential changes of the regulations were instituted in June 1900, and in 1907, one year after the reform of the penal code, a final modification accomplished the reform of the institute of police supervision. These reforms proved the efficiency of the reformists' propaganda as the new regulations in part reflected some arguments and criticisms of the discourse of reform. One essential result of the reform process was the new position acquired of welfare associations (Fürsorgevereine).

Welfare associations existed alongside police supervision for several decades before they rose to prominence with the new model of police supervision ${ }^{53}$. Charitable organisations such as the Association for the Betterment of Prisoners (Verein zur Besserung der Strafgefangenen, 1829) had been involved in the support and care of former prisoners for many decades. However, step by step the reform of police supervision entrusted a particular competence upon church and private welfare associations and allowed them to play a significant role approved by state authorities and sanctioned by the law. In this respect, the reform of police supervision must be viewed against the background of the general development of policing in Prussia. During the Imperial period the police began to pass on certain powers to private welfare associations ${ }^{54}$. Consequently, former opponents of police supervision began to support the new institution of police supervision which they had criticised so harshly in the preceding decades ${ }^{55}$.

The first reform initiated in 1895 put welfare associations in charge of the wages earned by prisoners during their prison sentence, the so-called "work bonus" (Arbeitsprämie). Previously the police had paid prisoners their whole earnings after their release from prison. From 1895 onwards welfare organisations were commissioned with the payment and with these funds at their disposal they had been provided with a lever. The bonus was not paid at once; to benefit from their little wage earned while in prison, known as the "gift of work" (Arbeitsgeschenk), released prisoners had to fulfil a first basic requirement of the regulation of police supervision: they were obliged to report to the local police authority ${ }^{56}$. The ex-prisoner should engage in the monitoring process and turn themselves into an "Observat". Additionally, the newly implemented regulations urged "to use the earning to the purpose of welfare and to oppose any abuse. ${ }^{, 57}$ Welfare associations were entitled to subject further payments to conditions and the overall progress of the former pris-

\footnotetext{
Hüchtker (1999); Grzywatz (1999); Lindner (2004, p. 99ff.)

Reinke (1991, p. 55). Cf. Meyer-Drawe (1996).

See Braune (1903, p. 760); idem (1889).

6 Decree 13.6.1895, in Braune (1903, p. 752).

57 Ibid.
} 
oner and, if he or she did not co-operate and comply with the instructions, the rest of the payment was to be submitted to the local police.

In 1900 further reforms were introduced which widened the scope of competences of the welfare organisations. In contrast to previous regulations the new instructions modified the relationship between the "Observat" and the police:

$\S 9$ / As long as a sentenced [person] is subjugated to regular care, all measures, which are apt to hinder his regular work, e.g. by police officers, are to be avoided. From time to time police authorities have to ask the welfare organisations whether the sentenced person has reported from the beginning and the ending of his care $^{58}$.

As long as a released prisoner was registered with a charitable organisation the police was obliged to avoid any contact, the police was required to ask the association about the terms of care. The welfare associations acted as a mediator between the police and the former prisoner. The police supervision "rested" (ruhte), and a "monitoring care" (beaufsichtigende Fürsorge) replaced police supervision as long as the "fosterling" did not indulge in idleness or misbehaviour" ${ }^{59}$.

Although leading members of the Interior Ministry considered it "a fundamental change" ${ }^{60}$, the final reform in 1907 confirmed details decreed already in June 1900 $(\$ 9)^{61}$. However, "subsequent to the Wilhelm Voigt case" ${ }^{62}$ the Prussian government obviously had to respond to the wide-ranging allegations made against it. During the revelations following the successful deception by the fake Captain and the arrest of the usurper in October 1906, it transpired that Voigt had once been a 'reformed' prisoner before being unreasonably expelled by local police authorities. Hence the Interior Ministry declared that from now on released prisoners who had found "honest labour" (ehrliche Arbeit) to make their living without the support of a welfare association, were to be spared any action of the police ${ }^{63}$. The government's public assertion of a "complete transformation of the police procedure" 64 dubbed by the Berlin press as "Lex Voigt" was supposed to convey an alleged willingness to further the policy of penal reform in view of the scandalous revelations subsequent to Voigt's arrest in October 1906. At least the subordinate institutions of the Interior Ministry, including the police, were again reminded of their recently constrained field of competences. The public announcements even went so far as to urge police authorities to encourage released prisoners to register with welfare associations, but even if they did not co-operate with any of these; they were, at least in theory, not to be expelled by the district police authority.

The reforms of police supervision did not result in an immediate change of practice. Time and again police authorities did not comply with the new restrictions of

58 GStA I. HA Rep. 84 Nr. 7935, Decree 30.6.1900.

59 Braune (1903, p. 754).

60 Schlichting/Reckes (1908, p. 375).

${ }_{61}$ GStA I. HA Rep. 84 Nr. 7935, Decree 30.6.1900; Braune (1908, p. 31).

62 Schlichtung/Reckes (1908, p. 375).

63 GStA I. HA Rep. 84 Nr. 7935, Decree 4.5.1907, 102; ibid., Writ 26.3.1907, 96.

64 Schlichting/Reckes (1908, p. 379). More important was the change of regulations about the requirements of references to be provided for the imposition of police supervision at the end of the prisoner's sentence, see GStA I. HA Rep. 84 Nr. 7935, Decree 21.3.1907, 99f., 99; Neиe Bestimmungen (1909, p. 279). 
their powers, but clung to their traditional concerns and measures of policing ${ }^{65}$. A further problem which surfaced after the initiation of reforms was the lack of communication between local police authorities and welfare associations ${ }^{66}$; some associations did not take on these new tasks, and in some regions of the Prussian Kingdom the associations which were supposed to perform the new police supervision did not exist ${ }^{67}$. However, charitable organisations had undeniably been bestowed with essential policing powers.

\section{THE PRUSSIAN POLICE, CIVILIAN POLICING AND THE PROFESSIONALIZATION OF POLICING}

It would be misleading to perceive the newly empowered welfare associations as being in opposition to the police. The task of welfare associations and their relationship to the police and the criminal justice system should be understood in terms of co-operation rather than antagonism, given their shared attitudes towards surveillance as well as overlap in administration and personnel.

The old institution of police supervision and the enhanced "powers of individualising" by the new monitoring authorities were historically related to the traditional "technology of pastoral care" (la 'technologie pastorale') in European history: its target is $\operatorname{man}^{68}$, in this case property offenders supervised to increase the society's safety and wealth ${ }^{69}$. The new policy towards prisoners revived the very idea of police supervision, the efficient interlacing of the former prisoners' industriousness and the surveillance of this process by a superior authority. Monitoring and reintegration were closely entwined in both models, even if the reformative programme informed by the knowledge and experience of missionary work ${ }^{70}$ - differed from the prevalent style of policing. In other words, to improve "the modern art of governing" (l'art moderne de gouverner) ${ }^{71}$ of former prisoners, the new monitoring care reformed the old institution of police supervision by borrowing extensively from a different "modality of pastoral care" (modalité de pouvoir pastorale) ${ }^{72}$.

Furthermore, welfare associations enjoyed the political support of the Interior Ministry which promoted - if not decreed - the establishment of a network of welfare associations in the Kingdom to ensure the provision of "monitoring care". In 1901 there were 384 associations; by 1914 the number of active welfare associations had reached 473. In Berlin alone there were three different institutions whose social activities included the care of ex-prisoners: the Verein zur Besserung der

\footnotetext{
65 Cf. Braune (1903, p. 758).

66 LAAB 14/1509, Writ of Oberpräsident Provinz Brandenburg, Potsdam 29.3.1913 [no pagination].

67 LAAB 14/1509, Writ of Schleßischer Provinzial-Verein, Breslau 12.5.1906 [no pagination]; see ibid., Anlage A and Anlage II. (...).

68 Braune (1903, p. 762); Foucault (1981, p. 136); cf. ibid. (pp. 155, 157, 159).

69 Foucault (1981, pp. 139, 136, 159, 161); idem (1977, pp. 719, 719f.). Cf. Bohlender (2001).

70 LAAB 14/1794, Martin Henning, Bericht über das Rauhe Haus in Hamburg, Hamburg 1904; Rohden (1908, p. 106f.); Dießenbacher (1986); Habermas (2008); cf. Foucault (1981, pp. 144 \& 155).

71 Foucault (1981, p. 159).

72 Foucault (1981, pp. 160 \& 136).
} 
Strafgefangenen, the Verein für die Berliner Stadtmission, the Evangelisch-kirchliche Vereinigung zur Fürsorge für entlassene Strafgefangene and, finally, the Fürsorge-Kommission der jüdischen Gemeinde ${ }^{73}$. Moreover, further administrative initiatives of the Prussian government reveal institutional ties between the Ministry and associations. Administrative co-operation was considered essential to ensure the effective functioning of the respective institutions. To prevent the "dispersal of forces and resources" (Zersplitterung von Kräften und Ressourcen), the Ministry decreed the establishment of "Central offices" (Zentralstellen) in June $1885^{74}$ inspired from the example of the South German State Baden ${ }^{75}$.

Finally, a glance at the membership of the Verein zur Besserung der Strafgefangenen in Berlin is quite revealing in trying to comprehend the mission of welfare associations. In 1902 the managing board (Direktorium) of this society included several counsellors of the Justice Ministry, members of the criminal justice system such as the president of the district court, the directors of Berlin's prisons Tegel and Moabit, and the chief of the police headquarters ${ }^{76}$. The leading management provided a platform of expertise across established institutional borders intended to facilitate co-operation and communication.

Although the police was not entirely marginalised, the differences between both institutions are palpable. The Prussian police was made to co-operate with an institutional body that differed with regard to its design, personnel, self-understanding, and comportment. While the Prussian police had its roots in the army, welfare associations sought to include leading state officials and directors from the judicial and penitentiary system as well as voluntary guardians, mainly of middleclass origin. Commissioned with the surveillance of ex-prisoners, guardians $(\text { Pfleger })^{77}$, a kind of social worker avant la lettre, eclipsed policemen who were deemed unfit to rekindle the "sense of honour" of former prisoners ${ }^{78}$. In Cottbus, the membership of the 'Society for the Welfare of Former Prisoners' comprised a superintendent, a missionary, a pastor, a precentor, a headmaster, a police officer, an archdeacon, a postman (Postschaffner), the wife of a town councillor, a court counsellor (Amtsgerichtsrat), a captain, a factory owner, a pharmacist, a noblemen, a state prosecutor, "and

73 LAAB14/1508, Anlage A zur Statistik der Strafanstalten pp. für 1901.

74 LAAB 14/1508, Bericht über die Wirksamkeit der Zentralstelle für das Gefangenen-Fürsorgewesen der Provinz Brandenburg im Rechnungsjahre 1903 nebst dem Verzeichnis der Preußischen Fürsorgevereine für entlassene Gefangene, Berlin 1904, Anlage B (1902), 3.

75 By 1901 ten central offices had been founded. In 1914 there were eleven of them, LAAB 14/1509, Anlage A zur Statistik der Strafanstalten pp. für 1901 and Anlage II. Nachweisung der in Preußen bestehenden Zentralstellen [...] und Vereine zur Fürsorge für Gefangene und Korrigenden.

76 LAAB 14/1508, Bericht über die Wirksamkeit des [...] Vereins zur Besserung der Strafgefangenen (1902), Berlin 1903, 5.

77 LAAB 14/1508, Bericht des Vereins in Cottbus (1901), Cottbus 1902, 13. In contrast to the private society in Cottbus, the association of the protestant church in Berlin did not only allow female volunteers to care for ex-prisoners several years later (1907), but also distinguished clearly between male "representatives" (Delegierte) and female "helpers" (Helferinnen) and their tasks and competences. Helpers were only allowed to assist if permission was granted by a male "representative". The clientele of helpers was confined to female convicts and families, see ibid., Jahresbericht der Evangelisch-kirchlichen Vereinigung zur Fürsorge für entlassene Strafgefangene Berlin (1904, 1905, 1906), Berlin 1907, 3; ibid., Instruction, 23.1.1906, 14.

78 LAAB 14/1508, Brochure of R. Braune, Pflege und Anregung des Ehrgefühls der Strafgefangenen, $37-45$. 
other ladies" $" 79$. The care and monitoring of former prisoners were no longer the privilege of the police; supervision of former prisoners was transformed into a social affair in which members of the public, at least those who could spare the required time and money, could participate and contribute. New labels for the old concept of police supervision were invented such as "care supervision" (Fürsorgeaufsicht), "monitoring care" (beaufsichtigende Fürsorge) or "civilian supervision" (bürgerliche Überwachung), reflecting the emphasis on care and the widening participation $^{80}$.

A further characteristic of the reform was the institutional continuity of the Prussian police. In contrast to other areas of police reform, such as the criminal investigation department, urban policing, female police, press policy ${ }^{81}$, the reform of police supervision did not entail any institutional changes of the Prussian police. Certainly, the police lost its overall responsibility and the empowerment of welfare associations partly removed the police from the supervision of released prisoners. The Prussian police, not only saved resources and personnel, but also avoided internal reform of its institution. The delegation of reform to welfare associations sheltered the police from the concern and the criticism of reform; the new "monitoring care" diverted the attention from the urgency of institutional change of the police. While the Interior Ministry was willing to embark on wide-ranging reforms which empowered charitable organisations, the Ministry spared the police from political change. The authoritarian bureaucratic practices of the police were still considered to be a necessary component of Prussian rule to safeguard the Kingdom's social and political stability. Although policing changed around the turn of the century, the reform of police supervision did not necessitate a reform of the Prussian police as such; the traditional policing lingered on $^{82}$.

\section{THE NEW INSTITUTION OF POLICE SUPERVISION}

The reform of police supervision sought to rekindle the idea of care and surveillance by implementing a new mode of policing. The former bureaucratic handling of police supervision by Prussian authorities was to give way to a new policy of monitoring care in the hands of the welfare societies which attempted to revive the traditional mission of police supervision, i.e. the efficient interlacing of police surveillance and the ex-prisoner's honest labour. In comparison with the "bureaucratic soldier" ${ }^{\prime 3}$ the role of the guardian of released prisoners differed accordingly:

With words and deeds, he takes charge of them, helps them to find work, has an eye on their way of life and seeks to prevent any relapse to crime by supporting them emotionally and economically ${ }^{84}$.

\footnotetext{
79 LAAB 14/1508, Bericht des Vereins in Cottbus (1901), Cottbus 1902, 13.

80 Braune (1903, pp. 753, 754, 755).

81 Reinke (1991), Spencer (1992), Nienhaus (1992), Johansen (2004), Müller (2005).

82 Funk (1986, p. 287ff.).

83 Reinke (1991, p. 55).

84 LAAB 14/1508, Bericht des Vereins in Cottbus (1901), Cottbus 1902, 3.
} 
The rigid handling of police supervision was replaced by an elaborated and differentiated set of strategies which addressed the shortcomings of the former practices of police supervision. The payment of the workbonus after the prisoner's release was transformed into a strategic use of this monetary resource to turn the released prisoner into a submissive "Observat". As soon as an "Observat" had requested the "monitoring care" by a welfare society, the "protégée" (Schützling) enjoyed the society's "Guarding supervision" 85 (Schutzaufsicht) and was, therefore, provided with a "personal identity card" (Ausweiskarte) which should protect him from any intrusive treatment by local police forces ${ }^{86}$. Thus the highly visible checks on the living and working of the 'policed' conditions gave way to a regular report of the "Observat" on a more or less voluntary basis ${ }^{87}$.

A further leitmotif of the new "monitoring care" was its emphasis on the individuality of the "Observat", echoing the main criticism voiced by reformers. In contrast to the seemingly arbitrary, schematic and "tormenting" application of police supervision $^{88}$, welfare associations deemed "the individualising power" 89 (le pouvoir individualisant) a promising method. The individual character of a released prisoner was to be taken into account in order to provide an appropriate control. Hence, additional documenting techniques were introduced. The "monitoring care" care was not complete without the accurate documentation of the "protégée's" (Schützling) situation and improvement. Associations in Berlin as well as in Görlitz had developed small cahiers (Fürsorgeaufsichtsbuch) to equip their volunteers with a means of regular recording for each fosterling ${ }^{90}$. The cover sheet provided personal details such as name, date of birth, place of birth, religious affiliation, and included particular information about occupation, employer, the latest sentence, previous convictions and the duration of the punishment. These "supervision reports" (Aufsichtsberichte) also recorded the "day of revision" and details about the observations $^{91}$.

85 Braune (188, p. 113) Rohden (1908, p. 125); Schlichting/Reckes (1908, p. 389 [E. Neckes]), Freudenthal (1912, p. 135).

86 LAAB 14/1508, Bericht des Vereins zur Besserung der Strafgefangenen (1902), Berlin, 1903, 17. Besides "observat" terms like "protégée", "fosterling" or simply "released" were frequently used denominations of reformists, e.g. Rohden (1908, pp. 116, 121).

87 One association practiced a set of diverse contacts between nurse and protégée and distinguished between initial "registration" (Anmeldung), "visit" (Besuch), and "report" (Meldungen), see LAAB 14/1508, Bericht des Vereins zur Besserung der Strafgefangenen (1902), Berlin 1903, 17.

88 Fuhr (1892, p. 229).

89 Foucault (1981, p. 136); Braune (1903, p. 762).

90 LAAB 14/1508, Bericht des Vereins zur Besserung der Strafgefangenen (1902), Berlin 1903, 17; LAAB 14/1509, Writ of Schleßischer Provinzial-Verein, Breslau 12.5.1906, Attachment 3 [no pagination]. If keeping a diary was feasible, Formularberichte were to be completed, LAAB 14/1509 Writ of Schleßischer Provinzial-Verein, Breslau 12.5.1906 Attachment 4 [no pagination]. The diary did not serve the nurse's purposes only, but would be presented to the associations' managing board, too.

91 LAAB 14/1509, Writ 12.5.1906, LAAB 14/1509, Writ of Schleßischer Provinzial-Verein, Breslau 12.5.1906, Attachment 3 . 


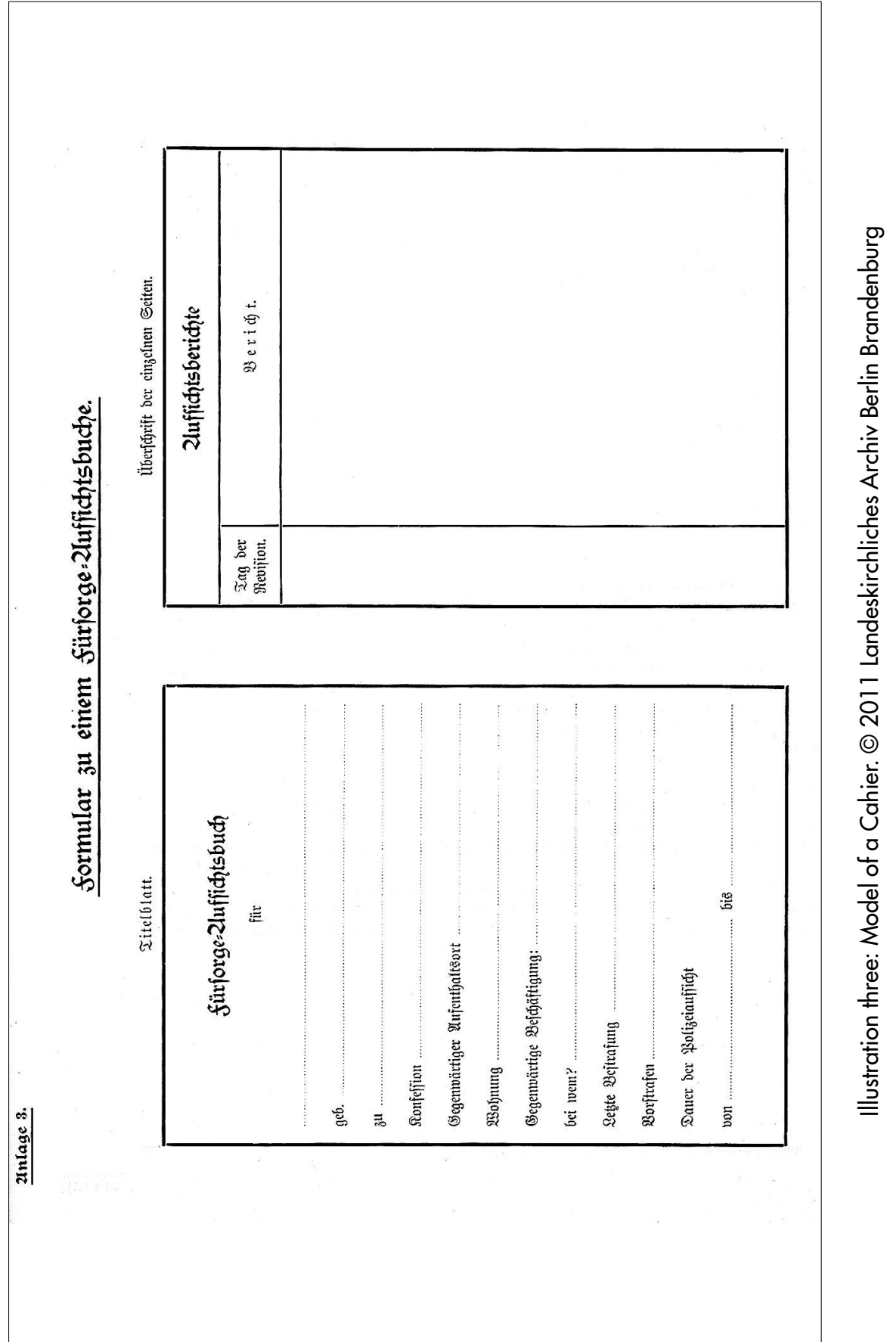


These cahiers helped the welfare supporters to remember encounters, to overview the development of the "protégée" (Schützling), and to provide evidence for his or her "characterisation" (Charakteristik). Furthermore, the cahier provided the associations with the means to instigate and justify further actions such as a "reward" (Prämie), admonition or expulsion"2. Most interestingly, it was the police who exploited, for its own purpose, this new expertise of the charitable organisations in "the knowledge of the human nature": Leading members of the Ministry and the police had publicly declared the suspension of any intervention in police supervision in 1907, but, in the subsequent years, the Berlin police headquarters requested with reference to the decree of the same year reports about the character of suspicious elements in order to expel them from the police district on the provision of the penal code ( $\S 38-39)$ and the 1842 Right to Residence Law ${ }^{93}$. Under the umbrella of the new "monitoring care" the police authority did continue with its more violent forms of policing although under changed circumstances of the post reform years.

However, "the great feat" of the monitoring care, as Pastor Pfeiffer put it, was to educate and accustom former prisoners to work for "the released deserved both help and - work." ${ }^{4}$ Welfare associations liaised with local employers, or they sent their "protégées" to the relevant employment agencies (Arbeitsbureau). Consequently, their "fosterlings" were placed as "craftsmen, writers, salesmen, servants, coachmen, earth-, field-, and brick workers. ${ }^{\circ 5}$

To support the reintegration process, welfare supporters had an arsenal of tools at their disposal ${ }^{96}$. A first contact, an informal chat provided the opportunity to check the "fosterling's" character: "one offers these people a seat" and signals social attention and interest; "one talks about their current accommodation and work" and thus reveals en passant their personal situation; "one is able to give them this or that advice" to provide them with essential information to live a "decent life"; "one provides them with a library card" because one cares about their edifying reading; one invites them "to the choir" because entertainment is a requisite of life as well; "one gives them a piece of clothing from our collection"; the most vulnerable of needy people $^{97}$. Last but not least, food vouchers and also small amounts of money were at the guardians' disposal. Advice could take different forms depending on the "fosterling's" character and individual situation. Furthermore, a key feature of all deployable strategies was their compound nature: they were neither pure forms of

92 LAAB 14/1508, Bericht des Vereins zur Besserung der Strafgefangenen (1902) Berlin 1903, 5; Cf. Foucault (1981, p. 145).

93 Aus dem preussischen Straffvollzug (1909, p. 14f.); LAAB 14/1509, Bericht der Zentralstelle (1907), Berlin 1908; ibid., Bericht der Zentralstelle (1910, 1911), Berlin 1911, $23 \mathrm{f}$.

94 LAAB 14/1508, Brochure of Pastor Pfeiffer (Berlin), Aus der Welt der Strafentlassenen, 9. The first attempt at reforming police supervision defined the work placement to be the welfare associations' very task, Decree 13.6.1895, in Braune (1903, p. 751). LAAB 14/1508, Jahresbericht Evangelischkirchliche Vereinigung Berlin (1904-1906), Berlin 1907, 2; Anonymous (1884, p. 154); Art. Gefängisvereine (1893, p. 116). Nurses of church associations were additionally commissioned with missionary tasks and had to make up for christening, wedding, etc., LAAB 14/1508, Jahresbericht Evangelisch-kirchliche Vereinigung Berlin (1904-1906), Berlin 1907, 13.

95 Anonymous (1887, pp. 466, 466ff.).

96 LAAB 14/1508, Jahresbericht Evangelisch-kirchliche Vereinigung, Berlin 1901, 8.

97 Braune (1903, p. 758). 


\section{Unlage 4.}

\section{Bezeichmung des fürforgeorgans:}

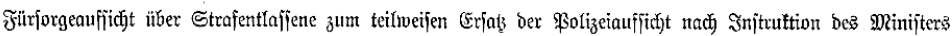

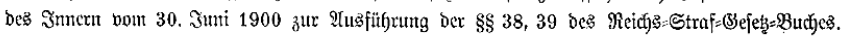

\begin{tabular}{|c|c|}
\hline $\begin{array}{c}\mathfrak{R a m} \text { a } \\
\text { Der zu beauffichtigenoen } \mathfrak{P e r j o u .}\end{array}$ & ( \\
\hline Woljung berjelben. & \\
\hline 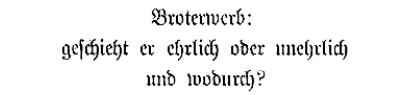 & \\
\hline $\begin{array}{l}\text { Untgang: } \\
\text { mit vrbentlichen voder untorbentfichen } \\
\text { Menichen? }\end{array}$ & \\
\hline 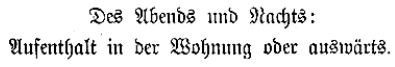 & \\
\hline Sonftiger fittlicjer $\mathfrak{B a n d e l .}$ & \\
\hline 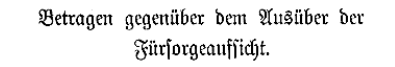 & \\
\hline 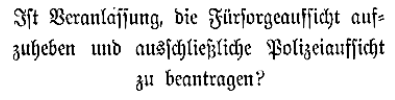 & \\
\hline Wer übt bie F̋üjorgeaufficut auş? & \\
\hline
\end{tabular}

Illustration four: Model of a Form @ 2011 Landeskirchliches Archiv Berlin Brandenburg 
material support nor mere means of surveillance, but a juxtaposition of both and provided the guardians with subtle and intricate means of intrusive help which tacitly suggested an industrious and law abiding way of life.

\section{DISTINGUISHING COMPETENCES: SOFT AND COERCIVE DISCIPLINARY MEANS}

However, these subtle strategies could not function efficiently without the threat and the application of coercive means. As Alf Lüdtke posits in a slightly different context, the "little stick" required the "big stick": ${ }^{88}$ Violence douce could not do without violence ouverte and the first did not render the latter superfluous. Each welfare supporter was equipped with a "card of legitimation" (Legitimationskarte), in order to ensure the support of local police forces in case of lacking respect, idleness or any kind of inappropriate behaviour while dealing with a "fosterling".

The "legitimating card" is indicative of a differentiation of roles and tasks of volunteers and policemen. The former was supposed to wield gentle disciplinary power to accustom the ex-prisoner to the rules of a "decent life." If the "fosterling" did not comply with the expectations of "civilian supervision," an indication of the guardian's disposal of police powers was possibly sufficient to restore the "fosterling" to "good order." The reformed mode of police supervision did not deprive the police of its role, particularly not of its competence in using coercive means. In contrast to new terms such as "fosterling", "welfare supervision" or the idea of an alleged "suspension of police supervision" "99, the police would be present throughout the monitoring care provided by welfare associations. If the threat looming large in the background did not suffice, a welfare supporter could still request the police to act according to its prevalent practice: displaying authority, possibly using physical force and, ultimately, expelling the non-compliant "Observat," if necessary.

The reformed police supervision did not suspend the punishment; it continued, but under changed circumstances. Permission to stay was provisional and depended on the "proof of real employment" and the conduct of the released prisoner. Both the police and the welfare associations could cancel the "provisional permission of residence" at any time during the whole period of supervision ${ }^{100}$. "Impudent behaviour" (freches Betragen), "indecent conduct" (ungebührliches Benehmen), noncompliance with regulations and orders or the suspicion of criminal activities, e.g. pimping and prostitution, prompted the suspension of the welfare associations' monitoring care and resulted, ultimately, in the expulsion of the 'policed' 101 .

The police continued to play an essential, albeit less evident, role within the reformed police supervision. From the sideline the police was essential for ensuring

\footnotetext{
Lüdtke (1979, p. 214).

Braune (1903, p. 754).

100 Schlichting/Reckes (1908, p. 384).

101 E.g. LAAB 14/1508, Bericht der Zentralstelle (1907), Berlin 1908, 18; ibid., Bericht des Vereins zur Besserung der Strafgefangenen (1906) Berlin 1907, 5 ; ibid., Bericht des Vereins zur Besserung der Strafgefangenen (1908), Berlin 1909, 222 ; LAAB 14/1509, Bericht der Zentralstelle (1908), Berlin 1909; ibid., Bericht der Zentralstelle (1910, 1911), Berlin 1911, 23f.; LAAB 14/1508, Bericht der Zentralstelle (1908), Berlin 1909, 22.
} 
law and order. For the police and welfare associations, the disciplinary effects resulting from the co-operation were an integral part of the reforms:

The penalised is under pressure for quite a while due to the threat of expulsion. In order to prevent his expulsion, he is compelled to keep to his work and to avoid any relapse into crime. So he becomes fond of work again, he accustoms an ordered way of life, although he is forced to it in the beginning ${ }^{102}$.

However, whether the new regulations succeeded in installing a new and efficient regime is a different matter.

\section{THE LIMITS OF REFORM AND CONSTRAINTS OF EFFICIENCY}

Welfare associations accounted for their own efficiency by counting the number of "fosterlings" they had put to work. However, the data provided by these statistics, listing the employment of released prisoners, do not lack the institution's bias. While the mere quantity of people put to work was the only indicator of success, the conditions and terms of the employment and particularly its duration were ignored, let alone considered the (mis-) match of skills and job requirements.

In order to demonstrate success, the guardians frequently used story telling as a mode of representatio. At the centre of the short account was the successful integration of a former prisoners: the protagonist was repeatedly hampered in his strive for a "decent life", but, thanks to the caring support of the story teller, the tragic victim of harsh and arbitrary policing measures was finally able to become what he wanted, a "respectable citizen". This heroic salvation of a lost soul can be conceived as a crystallised form of the experience of the work of reformers. Nevertheless, the affirmative morale of the narrator ignored the ambiguities, contradictions, and conflicts of monitoring care and served to congratulate the narrator for his strenuous efforts while taking care of his "protégées"103.

More revealing with regard to the new policy and its effects are the complaints and criticisms discussed by the supporters of the new police supervision after the reforms. The change of police supervision did not help to prevent the embarrassment of released prisoners. The "periodic report" 104 on the "fosterling" still generated contempt as both employer and employee were compromised ${ }^{105}$.

Another problem faced by reformers was the limited acceptance of help. It transpired that "the worst obstacle of welfare is always the fosterling"106. Former advocates of reform realised that their "protégées" allowed them "to help very occasionally"107; either because they did not ask for help or did not need it:

102 Ibid., (p. 384); see also LAAB 14/1508, Bericht des Verein zur Besserung der Strafgefangenen (1902), Berlin 1903, 5, 17.

103 Cf. Braune (1889, p. 829f.)

104 Braune (1903, pp. 757, 745).

105 LAAB 14/1509, Writ of Schleßischer Provinzial-Verein, Breslau 12.5.1906, Attachment 1: Copy of Writ of Oberpräsident der Provinz Schleßien, Breslau 9.8.1905 [no pagination].

106 Rohden (1908, p. 128).

107 Ibid. (p. 123). 
In accordance with the experience which we, the welfare-officials, are making, one could formulate the following paradox: Those who are really worthy, meaning they give well-founded hopes for improvement, are generally able to pull themselves together by their own means without our help; but those who urgently need our help are not worthy; they do not deserve our effort and work, they will drown again in the stream of perdition ${ }^{108}$.

The reformers' hope of utilizing their "fosterlings" "fall" as a lever proved illusionary. Released prisoners partially appreciated the work of welfare associations; particularly the buffer zone installed between welfare associations and police authorities was welcomed ${ }^{109}$. Furthermore, the "main task" 110 of the associations, i.e. the support in the search for a job, was often appropriated to a good effect. However, a commonly shared experience was, as Gustav von Rohden (1855-1942), a pastor and prison chaplain, noticed that:

...they do not ask for any more support, as soon as this aim has been achieved. Instead they are glad to escape their cumbersome and inferior position to the "guardian" and the welfare association ${ }^{111}$.

In the words of George Orwell, a man "humiliated" by receiving help "hates his benefactor" 112 . The calculated outcome of the new welfare policy failed; "fosterlings" reduced the offered welfare programme to a job agency; ignoring any further help they did not relapse to crime or breached any rules ${ }^{113}$. Their selective use of the support subverted a "fundamental" (tiefgreifend) and "full" (vollwertige) care and the welfare associations were "helpless" and "unsuccessful" 114 .

Traces at the margins provide further clues about the limits of the new policy pursued by welfare associations. Apart from lists of members, expenses, and statistics, some of the associations' "reports about [their] effectiveness" (Berichte über die Wirksamkeit) include anecdotes about positive outcomes and failures, summarising their experiences of "gains" and "losses."

Generally speaking, our protégées were thankful for the supplied work. However, there were also some exceptions. Example: / A man previously placed several times under police supervision was not able to resist his yearning for his wife who was still in prison; he abandoned work and ran into her arms. Five different released prisoners (Verurteilte) were reported, but they missed the connection somewhere and never arrived. An 'airman' (Luftfahrer, i.e. a vagrant) from 'Sonnenburg', who had already asked for work, but had not found any, was employed in construction for half a day; he explained then that he could not do such heavy

108 Rohden (1906, p. 186); cf. LAAB 14/1794, Martin Henning, Bericht über das Rauhe Haus in Hamburg, Hamburg 1904, 10.

109 LAAB 14/1509, Paper of Pastor Eichberg (Luckau), Alte Aufgaben und neue Wege in der Fürsorgearbeit an den Strafentlassenen, 1-36, 25; Anonymous (1887, p. 467).

110 Art. Gefängnisvereine (1893, p. 116).

111 Rohden (1908, p. 126).

112 Orwell (2001, pp. 185, 186). In this respect it is revealing that, in 1914, war disabled persons rejected help and care as they deemed it dishonourable; a concern shared by the Ministry of Interior, cf. GStA I HA Rep. 77 Tit. 227b Nr. 100 Bd. 12.

113 Rohden (1908, pp. 136, 127).

114 Ibid. (pp. 128, 124). 
work after a long period in gaol; he was too devitalised and almost collapsed with the handcart. He would be awfully sorry, and, by the way, he would be silk weaver. He vamoosed and as security he left a suitcase for the warden; content: a French Grammar. A third asked for a pair of waterproof boots which he indeed needed for his watery work at the river Spree, the more so as he had had to rest for several days already due to his rheumatism. But as soon as he had his pair of boots he made tracks and was not longer seen. We regretted the loss of the nice pair of boots; the innkeeper [regretted the loss of] the board wages ${ }^{115}$.

These brief stories were subject to a serious revision process before publication, and yet these few sentences encapsulate encounters of the "welfare volunteers" with their clientele. Given the obvious discrepancy between expectations, patterns of behaviour and values, the experience of these encounters was represented as "tidings" (nouvelles) about some kind of "infamous men" (hommes infâmes) ${ }^{116}$. The "fosterling's" conduct lacked any sort of match with the basic assumptions prerequisite for the monitoring care; their behaviour was at the margins of what was to be considered reasonable. Here in these "lives of a couple of lines or of a couple of pages" 117 surface the ultimate limits of care and surveillance and, at the same time, they reveal an enjeu different from the presumptions of a "decent life" and its necessary requirement, policing.

In conclusion, the co-operation of welfare associations and police established between 1895-1907 did not achieve the aims pictured by the agencies involved in the reform; the new "monitoring care" was bedevilled by old problems. To put it succinctly, the propagated effects of the "individualising power" (pouvoir individualisant) were exaggerated, the efficiency of the monitoring care overrated. In fact, the appropriation of the monitoring care, reducing the associations' welfare policy to a mere job agency, is indicative of a misleading, albeit flamboyant, symbolic nimbus of the "technology of pastoral care" and a desire of the ex-prisoners for a kind of government different from the current form of policing. "Being guided was a state" 118 , this is true, but it was a contested, vexed and conflicting state of being.

\section{CONTINUITY, CHANGE, AND THE "LONGUE DUREE" OF SILENCE}

The main results of the analysis of police supervision could be described in terms of continuity and change.

The former police supervision was characterised by its predominantly bureaucratic style to administering everyday aspects of social life. The policemen's enforcement of instructions, tacit assumptions about the subjects' obedience and the overall set of strategies were by and large informed by the prevalent bureaucratic approach of policing in Prussia. However, in contrast to the sabre-rattling notion of authority and power, the examination of the prevalent policing practices revealed a

\footnotetext{
115 LAAB 14/1508, Bericht des Vereins in Cottbus (1901), Cottbus 1902, 6; see also Zwangs-Fürsorge für entlassene Strafgefangene (1909, p. 629).

116 Foucault (1977, p. 237).

117 Ibid.

118 Foucault (1981, p. 146).
} 
juxtaposition of coercive intervention, authoritarian symbolic acts, and helplessness. The rigid and authoritarian application of punishment as well as the police's disinformation and frustration went together and enhanced each other. Whether it had disciplinary effects on the subjects, the insufficiency of practices, means and the legal foundations of police supervision were in their essence contradictory, and yet confirmed the status quo.

For advocates of reform this old type of policing was deemed counterproductive, arbitrary and unjust, because potential disciplinary effects of this type of policing were ignored ${ }^{119}$. The propaganda in favour of penal reform proved efficient as "monitoring care" was introduced with welfare associations at the centre. A new form of cooperation between state officials and "respectable citizens" was charged with the responsibility for ex-prisoners. Borrowing largely from the tradition of "pastoral technology", the monitoring care implemented an intricate "art of governing" (art de gouverner) to guarantee public safety.

The role of the police in the reformed police supervision is revealing. The police was to a large extent disengaged from the care of former prisoners, but it continued to loom in the background in a critical position. As a result of the reforms a new form of co-operation was established which ensured distinct, albeit interlocked, competences to both agencies. While welfare associations were in charge of the monitoring process, the police were to refrain from any intrusive interaction unless the "protégée" was disobedient. In any case of emergency, however, the police's traditional competences were required: the display of state power and the use of coercion. Given this persistent demand of the "big stick," the reforms of police supervision could not but spare the police from any change of its institutional organisation. Furthermore, the interlacing of the new with the old can also be observed in another aspect of the new police supervision. It was the police's most direct violent form of policing and its ultimate resort, i.e. the expulsion of a former prisoner, which, in accordance with the last reform in 1907, was based on the welfare associations' newly introduced techniques of personal identification documents. The police based its traditional resort to banishment on the data retrieved from the welfare associations who had made great efforts to individualise their clientele. The bureaucratic handling of police supervision did not cease with the reforms, but instead the administering of deviant subjects took on a more sophisticated form.

Another persistent phenomenon, if not a phenomenon of longue durée, is the silence of those placed under police supervision. There is no immediate trace of a personal voice which could reach us a hundred years later, and yet the presence of the 'policed' in the affairs discussed in this article is palpable. In this respect, the material itself, whether it originated from police authorities, advocates of penal reform, or from welfare associations, is revealing for one shared characteristic: Whenever the involved authorities accounted for the released prisoners, they had lost control of them. The ex-prisoner figured prominently in the constantly repeated narrative of tragic loss; in the edifying story of reformers about their strenuous - but finally successful - salvation of one lost soul; in short anecdotes about funny encounters with incompliant "fosterlings" 120 ; and transformed into numbers in the statistics of the welfare associations. In other words, whenever authorities lost sight,

\footnotetext{
119 Cf. Lüdtke (1979, p. 188).

120 Freudenthal (1912, p. 133f.).
} 
i.e. visual control, their accounts sought to compensate for the ex-prisoners invisibility. The police supervision and the discussion of its reform sought to re-create the presence of those who slipped out of reach as if noted numbers or written words could once again get hold of those who had disappeared. In view of the sudden independence after release from prison, the former prisoners were considered weak, "helpless" like a "castaway" and immature like "children" 121 . Yet their repeated disappearances were a powerful thorn in the side of the authorities in charge of the 'administered'. It was the very idea of helplessness and weakness encapsulated in notions such as "Observat" or "fosterling" that turned the disappearance of former prisoners into a force of change, i.e. a force of historical change.

\section{Philipp Müller \\ DAAD Francis Carsten Lecturer Department of History \\ School of Slavonic and East European Studies \\ University College London \\ Gower Street \\ UK - London WC1E 6BT \\ philipp.mueller@ucl.ac.uk}

\section{REFERENCES}

\section{Unprinted Materials}

Geheimes Staatsarchiv (GStA)

GStA I. HA Rep. 84a Nr. 7935 Polizeiaufsicht

GStA I. HA Rep. 77 Tit. 227b Nr. 100 Bd. 12 Spezialien in Bezug auf die Verpflichtung der Stadt Berlin zur Aufnahme, Bildung und Verpflegung von Ortsarmen und Vagabunden, Bezahlung der Transport, Kur- und Verpflegungskosten, 1893-1906

\section{Heimatmuseum Köpenick (HMK)}

Bildarchiv Postkarte Nr. 139/97

Bildarchiv Postkarte Nr. 437/00

Landesarchiv Berlin (LAB)

LAB A Pr. Br. Rep. 030-07 Nr. 1091, Personalakte des Königlichen Polizeipräsidiums zu Berlin, betreffend Voigt

Landeskirchliches Archiv Berlin-Brandenburg (LAAB )

LAAB 14/1508 Acta betr. : die Fürsorge für Strafgefangene (und deren Angehörige) 19011909

LAAB 14/1509 Acta betr. : die Fürsorge für Strafgefangene (und deren Angehörige) 19091938

121 Kr. (1883, p. 315); Braune (1884, pp. 106, 112); LAAB 14/1508, Berichte Verein Cottbus (1902), Cottbus 1903, 4; Rohden (1908, pp. 116, 121); Wulffen (1908, p. 131). 
LAAB 14/1794 Acta betr. : die Vereine und Anstalten der Inneren Mission

\section{Printed Materials}

Anonymous, Zwangs-Fürsorge für entlassene Strafgefangene, Blätter für Gefängniskunde, 1909, 43, pp. 622-630.

Anonymous, Berichte des Vereins zur Besserung von Strafgefangenen in Berlin vom 22.6.1886, 12.10.1886 16.11.1886 und 14.12.1886, Blätter für Gefängniskunde, 1887, 21, pp. 466-469.

Anonymous, Die Fürsorge für entlassene Strafgefangene im Königreiche Sachsen, Blätter für Gefängniskunde, 1884, 18, pp. 152-158.

Art. Gefängnisvereine, in: Blätter für Gefängniskunde, 1893, 27, pp. 112-117.

Aus dem preußischen Strafvollzug und Fürsorgewesen, Blätter für Gefängniskunde, 1909, 43, pp. 540-544.

Bahn, W., Meine Klienten. Beiträge zur modernen Inquisition, Berlin 1907 (Großstadt-Dokumente, 42).

Braune, R., Das Schutzwesen für Entlassene, Blätter für Gefängniskunde, 1884, 18, pp. 104117.

Braune, R., Wider die Polizeiaufsicht, Zeitschrift für die gesamte Strafrechtswissenschaft, 1889, 9, pp. 806-832.

Braune, R., Über die Polizeiaufsicht, Zeitschrift für die gesamte Strafrechtswissenschaft, 1903, 23, pp. 807-832.

Braune, R., Über die Polizeiaufsicht, Zeitschrift für die gesamte Strafrechtswissenschaft, 1908, 28, pp. 31-43.

Freudenthal, B., Die Aufenthaltsbeschränkung im Vorentwurf zu einem deutsche Strafgesetzbuch, Monatsschrift für Kriminalpsychologie und Strafrechtsreform, 1912, 8, pp. 132135.

Fuhr, K., Die Polizeiaufsicht nach dem Reichsstrafgesetzbuch: dogmatische Abhandlung, Gießen 1888.

Fuhr, K., Strafrechtspflege und Sozialpolitik. Ein Beitrag zur Reform der Strafgesetzgebung auf Grund rechtsvergleichender und statistischer Erhebungen über die Polizeiaufsicht, Berlin, 1892.

Goltdammer, Th., Materialien zum Strafgesetzbuch für die Preußischen Staaten, Berlin, 1851.

Höhl, B., Die Polizeiaufsicht. Eine dogmat.-krit. Studie, Würzburg, 1915.

Hübner, P., Unter Polizeiaufsicht. Orig. Posse mit Gesang in 1 Akt von Paul Hübner. Musik von Richard Thiele, Mühlhausen i. Th., 1900.

Kr., Das Schutzwesen für entlassene Gefangene, Blätter für Gefängniskunde, 1883, 17, pp. 315-318.

Neue Bestimmungen über die Überwachung bestrafter Personen nach der Strafverbüßung, Blätter für Gefängniskunde, 1909, 43, pp. 273-281.

Nussbaum, A., Die landesgesetzlichen Aufenthaltsbeschränkungen bestrafter Personen, Zeitschrift für die gesamte Strafrechtswissenschaft, 1905, 25, pp. 345-382.

Orwell, G., Down and Out in London and Paris, London [1933] 2001.

Rohden, G. v., Einige wichtigere Probleme der Entlassenenfürsorge, Monatsschrift für Kriminalpsychologie und Strafrechtsreform, 1906, 2, pp. 184-196.

Rohden, G. v., Probleme der Gefangenenseelsorge und Entlassungsfürsorge, Gießen, 1908. 
R., E., Die Fürsorge für entlassene Strafgefangen in Württemberg, Blätter für Gefängniskunde, 1884, 18, pp. 159-162.

Rosenfeld, E., Neues aus der Fürsorge für Strafentlassene in Deutschland, insbesondere Neuregelung der Invalidenversicherung, Polizeiaufsicht und vorläufige Entlassung, Monatsschrift für Kriminalpsychologie und Strafrechtsreform, 1910, 6, pp. 295-310.

Schlichting, Reckes, Welche Aufgaben fallen den Organen der Entlassenenfürsorge bei Ausführung der neuen preußischen Ministerialerlasse betr. die Ausweisung Bestrafter zu?, Zeitschrift für die gesamte Strafrechtswissenschaft, 1908, 28, pp. 375-390.

Sudermann, H., Stein unter Steinen. Schauspiel in vier Akten, Stuttgart, Berlin, 1905.

Wagner, Die Rettungsanstalt für entlassene weibliche Strafgefangene ev. Confession zu Oberurbach, O.-A. Schorndorf: Königreich Württemberg, Blätter für Gefängniskunde, 1886, 20, pp. 377-396.

Wulffen, E., Zur Frage der Entlassenenfürsorge, Monatsschrift für Kriminalpsychologie und Strafrechtsreform, 1908, 4, pp. 128-131.

Zeller, P., Systematisches Lehrbuch der Polizeiwissenschaft, Quedlinburg, Leipzig, 1828.

Zille, H., Kinder der Strasse. 100 Berliner Bilder, Berlin, 1908.

Zimmermann, C.W., Die Diebe in Berlin oder Darstellung ihres Entstehens, ihrer Organisation, ihrer Verbindungen, ihrer Taktik, ihrer Gewohnheiten und ihrer Sprache, Leipzig, 1979 [1847].

Zwangs-Fürsorge für entlassene Strafgefangene, Blätter für Gefängniskunde, 1909, 43, pp. 622-630.

\section{Literature}

Becker, P., Von der Biographie zur Genealogie: Zur Vorgeschichte der Kriminologie als Wissenschaft und diskursiver Praxis, in Bödeker, H.-E., Wissen als kulturelle Praxis, Göttingen, 1999, pp. 335-377.

Becker, P., Verderbnis und Entartung: eine Geschichte der Kriminologie des 19. Jahrhunderts als Diskurs und Praxis, Göttingen, 2002.

Bohlender, M., Metamorphosen des Gemeinwohls. Vom der Herrschaft guter polizey zur Regierung durch Freiheit und Sicherheit, in Münkler, H., Bluhm, H., Gemeinwohl und Gemeinsinn. Historische Semantiken politischer Leitbegriffe, Berlin, 2001, pp. 248-274.

Caplan, J., 'Speaking scars'. The Tattoo in popular practice and medico-legal debate in nineteenth-century Europe, History Workshop Journal, 1997, pp. 107-142.

Dießenbacher, H., Der Armenbesucher: Missionar im eigenen Land. Armenfürsorge und Familie in Deutschland um die Mitte des 19. Jahrhunderts, in Sachße, Ch., Tennstedt F., Soziale Sicherheit und soziale Disziplinierung. Beiträge zu einer historischen Theorie der Sozialpolitik, Frankfurt a.M., 1986, pp. 209-244.

Evans, R.J., Tales from the German Underworld: Crime and Punishment in the Nineteenth Century, London, 1998.

Foucault, M., Surveiller et punir. Naissance de la prison, Paris, Gallimard, 1975.

Foucault, M., Power and Norms, in Morris, M., Patton, P., Power, Truth, Strategy, Sydney, 1979, pp. 59-66.

Foucault, M., Omnes et singulatim. Vers une critique de la raison politique, in Dits et Écrits, Vol IV, Paris, Gallimard [1981] 1994a, pp. 134-161.

Foucault, M., Sécurité, territoire et population, in Dits et Écrits, Vol III, Paris, Gallimard [1978] 1994b, pp. 723-719. 
Foucault, M., La vie des hommes infâmes, in Dits et Écrits, Vol III, Paris, Gallimard [1977] 1994c, pp. 237-253.

Foucault, M., Sécurité, territoire, population. Cours au Collège de France. 1977-1978, Paris, Gallimard, 2005.

Funk, A., Polizei und Rechtsstaat: die Entwicklung des staatlichen Gewaltmonopols in Preußen 1848-1918, Frankfurt a.M., 1986.

Grzywatz, B., Armenfürsorge im 19. Jahrhundert. Die Grenzen der kommunalen Daseinsvorsorge, Zeitschrift für Geschichtswissenschaft, 1999, 47, pp. 583-614.

Habermas, R., Von Anselm von Feuerbach zu Jack the Ripper. Recht und Kriminalität im 19. Jahrhundert. Ein Literaturbericht, Zeitschrift für Rechtsgeschichte, 2003, 3, pp. 128165.

Habermas, R., Eigentum vor Gericht. Die Entstehung des modernen Rechtsstaates aus dem Diebstahl?, Werkstatt Geschichte, 2006, 42, pp. 25-43.

Habermas, R., Mission im 19. Jahrhundert. Globale Netzwerke des Religiösen, Historische Zeitschrift, 2008, 287, pp. 629-679.

Habermas, R., Rechts- und Kriminalitätsgeschichte revisited - ein Plädoyer, in Habermas, R., Schwerhoff., G., Verbrechen im Blick. Perspektiven der neuzeitlichen Kriminalitätsgeschichte, Frankfurt a.M., 2009a, pp. 19-41.

Habermas, R., Diebe vor Gericht, Die Entstehung der modernen Rechtsordnung im 19. Jahrhundert, Frankfurt a. M., 2009b.

Hett, B. C., The Captain of Köpenick and the transformation of German Criminal Justice, Central European History, 2003, 36, pp. 1-43.

Hett, B. C., Death in the Tiergarten. Murder and criminal justice in the Kaiser's Berlin, Cambridge Mass., 2004.

Hüchtker, D., «Elende Mütter» und «liederliche Weibspersonen»: Geschlechterverhältnisse und Armenpolitik in Berlin (1770-1850), Münster, 1999.

Johansen, A., Soldiers as police. The French and Prussian armies and the policing of popular protest, 1889-1914, Aldershot, 2004.

Johansen, A., State bureaucrats and local influence on the use of military troops for Maintenance of Public Order in French and Prussian industrial areas, 1889-1914, Crime, Histoire et Sociétés/Crime, History \& Societies, 2001, 5, pp. 53-73.

Lindner, R., Walks on the Wild Side. Eine Geschichte der Stadtforschung, Frankfurt a.M., 2004.

Lüdtke, A., The role of state violence in the period of transition to industrial capitalism. The example of Prussia from 1815 to 1848, Social History, 1979, 4, pp. 175-221.

Lüdtke, A., «Gemeinwohl», Polizei und «Festungspraxis». Staatliche Gewaltsamkeit und innere Verwaltung in Preußen 1815-1850, Göttingen, 1982.

Lüdtke, A., Police and State in Prussia 1815-1850, Cambridge, 1989.

Lüdtke, A., Herrschaft als soziale Praxis, in Lüdtke, A., Herrschaft als soziale Praxis. Historische und sozial-anthropologische Studien, Göttingen, 1991, pp. 9-63.

Meyer-Drawe, K., Versuch einer Archäologie des pädagogischen Blicks, Zeitschrift für Pädagogik, 1996, 42, pp. 655-664.

Müller, Ph., Journalistische Vermittlung und ihre Aneignung: öffentliche Verhandlungen über den Fall Wilhelm Voigt in Berlin 1906/08, Österreichische Zeitschrift für Geschichtswissenschaften, 2002, 13, pp. 35-56.

Müller, Ph., Auf der Suche nach dem Täter. Die öffentliche Dramatisierung von Verbrechen im Berlin des Kaiserreich, Frankfurt a.M., 2005.

Müller, Ph., Grenzen der preußischen Polizeiaufsicht 1870-1914, in Gebhardt, H., Polizei und Recht-eine wechselvolle Geschichte, Graz, 2006, pp. 59-73. 
Nienhaus, U., Einsatz für die „Sittlichkeit”. Die Anfänge der weiblichen Polizei im Wilhelminischen Kaiserreich und der Weimarer Republik, in Lüdtke, A., "Sicherheit» und «Wohlfahrt». Polizei, Gesellschaft und Herrschaft im 19. und 20. Jahrhundert, 1992, pp. 243-266.

Reinke, H., «Großstadtpolizei». Städtische Ordnung und Sicherheit und die Polizei in der Zeit des Kaiserreich (1871-1918), in Dinges, M., Sack, F., Unsichere Großstädte. Vom Mittelalter bis zur Postmoderne, Konstanz, 2000, pp. 217-240.

Reinke, H., «Das Amt der Polizei». Eine Einleitung, in Reinke, H., «...nur für die Sicherheit da...»? Zur Geschichte der Polizei im 19. und 20. Jahrhundert, Frankfurt a.M., 1993, pp. 3-32.

Reinke, H., «Armed as if for a war.» The state, the military and the professionalization of the Prussian Police in Imperial Germany, in Emsley, C., Weinberger, B., Policing in Western Europe 1850-1940. Politics, professionalization and public order, New York, 1991, pp. 55-73.

Roth, A., Kriminalitätsbekämpfung in deutschen Großstädten 1850-1914. Ein Beitrag zur Geschichte des strafrechtlichen Ermittlungsverfahrens, Berlin, 1997.

Schulte, R., Sperrbezirke, Tugendhaftigkeit und Prostitution in der bürgerlichen Welt, Frankfurt a.M., 1979.

Spencer, E.G., Police and the Social Order in German Cities. The Düsseldorf District, 18481918, DeKalb Ill., 1992.

Spencer, E.G., Police military relations in Prussia 1848-1914, Journal of Social History, 1985,19 , pp. 305-317. 